\title{
INDUSTRIALIZAC̣̃̃O ENQUANTO PROGRESSO NOS LIVROS DIDÁtICOS DE HISTÓRIA DO BRASIL, 1972-2012
}

Industrialization through progress in Brazilian History textbooks, 1972-2012

\section{RESUMO}

As representações presentes nos livros didáticos são um dos elementos que informam a consciência histórica produzida em uma sociedade moderna. O objetivo desta pesquisa é entender as representações de industrialização e como elas estão associadas à ideia de progresso nos livros didáticos de história do Brasil voltados para o Ensino Médio e publicados entre 1972 e 2012. Da análise de 88 livros, depreende-se, inicialmente, que a história da representação de progresso pode ser apresentada como a "redenção nacional". Posteriormente, o discurso de progresso é deslocado para a desigualdade social e, apenas no século $\mathrm{XXI}$, a desigualdade ambiental começa a ser problematizada. Todavia, a persistência de uma representação da industrialização como progresso continua a fazer parte da narrativa escolar da história do Brasil.

Palavras-chave: Livros didáticos; Ensino de história; Progresso; Industrialização; Meio ambiente.

\begin{abstract}
The representations found in textbooks are one of the elements that report the historical awareness produced in a modern society. The objective of this study is to understand the representations of industrialization and how they are associated with the idea of progress in Brazilian history textbooks for high school, published between 1972 and 2012. Through the analysis of 88 books, it was clear, initially, that the history of the representation of progress can be presented as a "national redemption". Subsequently, the discourse of progress is shifted to social inequality and, only in the twentyfirst century, did environmental inequality begin to be discussed. However, the persistence of a representation of industrialization as progress continues to be part of the academic narrative of the history of Brazil.
\end{abstract}

Keywords: Textbooks; Teaching history; Progress; Industrialization; Environment. 


\section{Introdução}

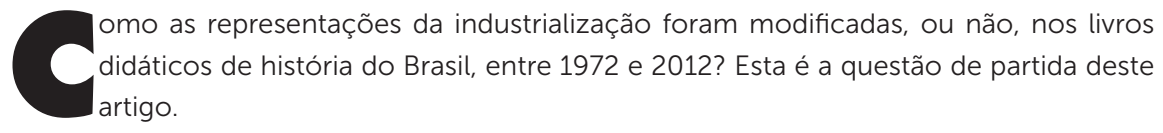

Em 1972, a Conferência Mundial do Meio Ambiente Humano, em Estocolmo, foi o grande marco da internalização da moderna questão ambiental. A posição brasileira pode ser resumida na afirmação do governo brasileiro: "tragam sua poluição para o Brasil desde que as fábricas venham junto". Ou seja, industrializar o Brasil era a prioridade do governo e os problemas socioambientais eram vistos como um custo aceitável perante os benefícios do "progresso" trazidos pela industrialização. Afirmava-se que era necessário "fazer o bolo crescer para depois distribuir", ou seja, fazer a economia crescer para depois resolver a "dívida social", em uma época em que se efetuou a industrialização baseada na concentração de renda. O discurso do progresso justificava tais políticas concentracionistas (FURTADO, 1974).

A Conferência de Estocolmo foi, também, um marco significativo de um esforço internacional na implementação da educação ambiental nos sistemas educacionais em todos os países do planeta Terra. De fato, a questão ambiental deixou de ser uma preocupação de especialistas para saltar ao primeiro plano do cenário político (McCORMICK, 1992). Em países como o Brasil, todo um sistema legal e institucional foi criado para promover a educação ambiental, consagrando a noção de que a educação ambiental não deveria ser uma especialidade, uma nova disciplina, mas uma prática e um saber transversal às disciplinas acadêmicas e escolares clássicas.

A Conferência das Nações Unidas sobre o Meio Ambiente e Desenvolvimento, no Rio de Janeiro, em 1992, a maior reunião de chefes de estado da história, legitimou o conceito de desenvolvimento sustentável e deu um grande impulso à educação ambiental no Brasil. Há uma hegemonia da noção de desenvolvimento sustentável. Politicamente, mesmo os setores associados às atividades que mais degradam os ecossistemas passaram a ter que se apresentar na esfera pública como "ecologicamente corretos" (BARBOSA, 1991). Todavia, a hegemonia da noção de desenvolvimento sustentável não implica que a economia tenha caminhado para uma verdadeira sustentabilidade socioambiental. Como afirma Leff, o conceito de desenvolvimento sustentável, tal como consagrado na Rio-92, acaba por tentar, na prática, transformar a natureza em "capital natural" sem alterar a lógica econômica que governa as ações. O que, para o autor, leva a um beco sem saída, no qual toda tentativa de gestão racional-científica-econômica do ambiente está previamente condenada ao fracasso, pois não passa dos pressupostos centralizadores, homogeneizadores e de valorização econômica que estão na base da própria racionalidade econômica que deu origem à crise ambiental (LEFF, 2006, p. 137). 
Vinte anos depois, a Organização das Nações Unidas realiza a Conferência das Nações Unidas sobre Desenvolvimento Sustentável, que ficou conhecida como Rio+20. A agenda de desenvolvimento sustentável da Rio-92 não foi implementada em muitos pontos e a crise econômica mundial de 2008 mostrou claramente que, entre medidas para um "desenvolvimento sustentável" e medidas que garantam a sustentabilidade do desenvolvimento econômico, os governos optaram prioritariamente pela segunda opção. Ao mesmo tempo que, na divisão internacional do trabalho, vem sendo acentuado o papel de países como o Brasil como fornecedor de matérias-primas, o crescimento das exportações esteve centrado no setor primário em detrimento de políticas voltadas para a industrialização (GILJUM; EISENMENGER, 2004).

Dentro do quadro de tal recorte temporal - 1972 a 2012 - de profundas mudanças na forma como se entende a relação entre indústria e ambiente, este artigo aborda as representações de industrialização, em especial sua relação com a noção de progresso. Sendo o processo de industrialização não apenas uma mudança de bases técnicas ou um fenômeno econômico, uma vez que implica uma completa reconfiguração social (HOBSBWAM, 2000, p. 203-220).

Neste texto não se trata de debater as teorias explicativas dos processos de industrialização (IORIS, 2014), pois não se segue o caminho de estudar os livros didáticos para entender "o processo de difusão do conhecimento científico" (ALMEIDA, 2005, p. 75). Minorelli analisa quatro livros didáticos mais vendidos para os anos finais do Ensino Fundamental e aponta que, ao trabalharem a Revolução Industrial inglesa, o referido tema é abordado apenas em suas dimensões técnicas e sociais. Apenas um livro faz referência a questões "ambientais", mas não em seu corpo principal. A autora busca apontar formas de como o tema ambiental poderia ser trabalhado a partir da história ambiental recentemente produzida (MINORELLI, 2011).

Os livros didáticos articulam uma produção intelectual de instituições peritas que produzem um conhecimento especializado, com um público mais amplo, em especial as escolas - instituição fundamental de formação da consciência histórica no mundo moderno (RÜSEN, 2011). Todavia, não há um processo de difusão do conhecimento de produtores para consumidores, admitindo que "todo consumo é, também, produção" (CHARTIER, 2002, p. 51), pois cada um desses lugares sociais tem sua própria lógica de produção do conhecimento. O saber escolar é distinto do saber acadêmico. O saber escolar e a "consciência histórica" são produzidos na escola, por muitos outros meios de comunicação e pela apropriação feita por alunos e professores, de forma que produzem sua própria narrativa. Desenvolver a "competência narrativa" como postulada por Rüsen é uma atividade da "vida prática":

A narração histórica é mais do que uma simples forma específica de historiografia. Intérpretes contemporâneos dessa discussão (por exemplo, Hayden White e Paul Ricoeur) apresentam a narração histórica como um procedimento mental básico que dá sentido ao 
passado com a finalidade de orientar a vida prática através do tempo (RÜSEN, 2011, p. 37).

Não é pretensão deste trabalho dar conta das formas de apropriação pelos alunos ou professores, mas entender, valendo-se deste lugar de conexão entre a academia e os alunos das escolas - que é o livro didático - qual a representação da industrialização na história do Brasil. E, mais especificamente, como a industrialização é articulada à noção de progresso.

Trata-se de uma análise de conteúdo que não desconsidera os aspectos pedagógicos e a materialidade do livro didático (CHOPPIN, 2004). O livro didático é produzido a partir de um lugar social específico em que cruzam inúmeras linhas de forças que devem ser explicitadas para a compreensão efetiva de tal material. Assim, pode-se acompanhar Bittencourt (1993, p. 3), segundo a qual os livros didáticos são tomados simultaneamente como:

[...] material impresso, estruturado, destinado ou adequado a ser utilizado num processo de aprendizagem ou formação; materiais caracterizados pela seriação dos conteúdos; mercadoria; depositário de conteúdos educacionais; instrumento pedagógico; portador de um sistema de valores; suporte na formulação de uma História Nacional; fontes de registros de experiências e de relações pedagógicas ligados a políticas pedagógicas da época; e ainda como materiais reveladores, de ângulos do cotidiano escolar e do fazer-se da cultura nacional (BITTENCOURT, 1993, p. 3).

As fontes abordadas são os livros da história do Brasil ou de história do Brasil e história geral integrados, utilizados no Ensino Médio do Ensino Básico, antigo Segundo Grau. A Biblioteca de Livros Didáticos da Faculdade de Educação da Universidade de São Paulo possui o maior acervo deste tipo de material no Brasil, sendo consultado todos os livros disponíveis no acervo com as características supracitadas. Assim, foram utilizados na pesquisa 76 livros com as características citadas levantados na biblioteca, além de outros 12 livros que correspondem ao acervo particular do autor. ${ }^{1}$

Da análise do material identificaram-se três momentos na história da representação da industrialização brasileira. Em um primeiro momento, na década de 1970, a industrialização é a "nossa redenção"; num segundo, a industrialização é inserida em uma ótica de conflito de classes; e, em um terceiro momento, é abordada a incorporação parcial e fragmentada dos problemas socioambientais interligados ao processo de industrialização. Todavia, mais que descontinuidade, é a continuidade de uma noção de progresso associado à representação de industrialização que marca mais frontalmente os resultados da pesquisa.

\section{"Nossa" industrialização redentora}

Na década de 1970 havia dois tipos básicos de livros didáticos disponíveis no mercado brasileiro. Um primeiro tipo correspondia à continuidade dos livros produzidos nas décadas de 1930 a 1960 e que ainda eram amplamente editados no início da década de 1970. Tais livros em geral são apresentados como centrados em uma velha história política, (vista de 
"cima", a partir do ponto de vista do establishment), uma história factual e voluntarista, ou seja, centrada em acontecimentos e não percebendo as forças estruturais de transformação, acabando por descrever os rumos da história como resultado da ação de heróis geniais e valentes, em geral alojados no poder de Estado. Certamente havia uma série de perspectivas diferentes sobre a história. Apesar de simplificadora, a descrição supra não está incorreta. Sendo que o:

[...] período compreendido entre as décadas de 1930 e 1960 caracterizou-se, no que diz respeito aos manuais escolares, da seguinte forma: foram livros que permaneceram por longo período no mercado sem sofrerem grandes alterações; livros que possuíam autores provenientes de lugares tidos, naquela época, como de alta cultura, como o Colégio D. Pedro II; livros publicados por poucas editoras que, muitas vezes, não os tinham como mercadoria principal e, por fim, livros que não apresentavam um processo de didatização e adaptação da linguagem consoante às faixas etárias às quais se destinavam (GATTI JÚNIOR, 2007, p. 37).

Contudo, como adverte Gatti Júnior, até a década de 1960 o livro didático de história não era um elemento central nas salas de aula. O ensino se desenvolvia de forma bastante autônoma ao referido material didático.

A partir do acordo do governo brasileiro com a Agência Norte-Americana para o Desenvolvimento Internacional (USAID, na sigla em inglês), em 1966, que levou à constituição da Comissão do Livro Técnico e Didático e garantiu financiamento para a compra de miIhões de livros pelo governo, houve uma massiva ampliação da utilização e do papel dos livros didáticos no Brasil. A ampliação do sistema educacional público no Brasil se deu a expensas da qualidade do ensino e, por isso, vários autores preferem referir-se ao processo como massificação do ensino. Enquanto o sistema público era destinado principalmente à parte rica da sociedade, o ensino era de melhor qualidade, mas quando o ensino público conseguiu abarcar paulatinamente e parcialmente a população pobre, a qualidade do ensino nas escolas públicas em geral, decaiu havendo a migração da classe média e alta para as escolas particulares. Em tal contexto, o livro didático tornou-se o elemento central e estruturante das aulas. Diante da carência de formação dos professores, da falta de infraestrutura das escolas e de condições adequadas de trabalho, a maioria dos professores tornou-se dependente do livro didático. Assim, se popularizaram nas escolas os livros do tipo "estudos dirigidos" nos quais o estudante tinha um exemplar com o texto e um questionário, livros "consumíveis", e o professor tinha um exemplar diferente com as perguntas respondidas. Um modelo tecnocrático de educação.

Os dois tipos de livros didáticos descritos acima são convergentes em uma dada representação do processo de industrialização, a qual pode ser designada de "nossa industrialização redentora". O livro História do Brasil, de Armando Souto Maior, em 1974, estava em sua décima edição. É um exemplo de livro escrito a partir do ponto de vista do establishment. Ao afirmar sobre o "nosso futuro" diz: 
O contínuo desenvolvimento da nossa industrialização é uma necessidade para o povo brasileiro. A indústria concorre para a melhoria da produtividade do trabalho, permitindo-lhe receber remuneração mais alta; abre ao operário maiores horizontes de consumo; educa a mão-de-obra, qualificando-a e especializando-a, e incentiva o desenvolvimento cultural pela criação de um mercado para técnicos e pesquisadores. A industrialização é o meio próprio para a realização das justas aspirações de que nosso povo tem de participar, de maneira crescente, das vantagens materiais da civilização moderna (SOUTO MAIOR, 1974, p. 354-355).

Um elemento importante a ser entendido no texto é o uso do pronome "nosso", buscando criar uma identificação do leitor com o Brasil, em um discurso nacionalista que silencia sobre as diferenças sociais. O Brasil é tratado como uma grande empresa de tal forma que eram possíveis afirmações como: "em 1940, devido à necessidade de substituirmos as importações, pois os nossos fornecedores estavam em guerra, elaborou-se um Plano Quinquenal, que deu origem, em 1941, à Companhia Siderúrgica Nacional" (LUCCl, 1979 , p. 248, grifo nosso). Assim, todo brasileiro deveria se sentir responsável pelo projeto de construir uma nação industrial.

Armando Souto Maior (1974, p. 353, grifo nosso) também afirma, em seu livro didático, que:

\begin{abstract}
Presidência Garrastazu Médici - [...] O trecho, abaixo transcrito, sintetiza o pensamento do atual Presidente e a orientação que pretende imprimir à sua administração: '[...] $\mathrm{Na}$ marcha para o desenvolvimento o povo não pode ser espectador. Precisamos reproduzir na vida político-administrativa aquilo que conseguimos até hoje nas atividades esportivas ou artísticas. De fato, é significativo que tenhamos obtido triunfos exatamente naqueles setores em que ocorre uma entusiástica e comovida participação do povo. Confesso lealmente que gostaria que o meu governo viesse a receber o prêmio da popularidade'.
\end{abstract}

Como afirma Elias, "a mais ampla distribuição de poder [...] é uma concomitante e uma condição para a industrialização" (ELIAS, 1997, p. 309). No Brasil, todavia, isto se dá de forma autoritária a partir do Estado.

Ao contrário do pensamento liberal, dominante no Império e ainda hegemônico na República Velha, via-se agora - e aí reside em grande parte a originalidade do pensamento autoritário no Brasil um total descompasso entre as instituições brasileiras e a realidade do povo. O Império, com sua fantasia britânica, e a República, de fraque e cartola, constituíam um verniz inautêntico recobrindo um país real doente, pobre e enfraquecido: Para dar consistência, autenticidade, à vida nacional e às suas instituições era necessário incorporar as grandes massas de marginais ao processo produtivo nacional (LINHARES; SILVA, 1999, p. 86).

Na Primeira República, a ideia, então hegemônica, era a de um país com "vocação agrícola". O Brasil deveria ser um produtor de bens primários, de acordo com os princípios liberais que consagravam uma divisão internacional do trabalho, dado a "vantagens competitivas" por uma "ordem natural" organizada pela "mão invisível" do mercado. Foi a crise 
no sistema capitalista de 1929 que mostrou para a elite brasileira e de várias outras partes do mundo, o quão perigoso era ser dependente de um único produto de exportação, ainda mais um produto não essencial como o café, no caso brasileiro. Conforme afirma Silva, a "Revolução de 1930" marca uma mudança na configuração das elites no poder, já que, até então, o Estado brasileiro havia protegido essencialmente os interesses agraristas e a partir daí a agricultura adquire uma função dentro de um projeto industrializante (SILVA, 1998, p. 115). Ou, melhor, adquire variadas funções dependendo de diferentes projetos industrializantes. O elemento convergente nos vários projetos de industrialização era a certeza de que esse era o sentido a ser perseguido e que tal meta era positiva. Ou, dito de outra forma, a convergência era a ideia de progresso (LE GOFF, 1996, p. 234).

Nos livros didáticos citados as atividades que levaram ao desenvolvimento industrial são frequentemente adjetivadas positivamente. Como na passagem sobre o segundo governo Vargas: "Não foi possível a Getúlio Vargas um governo de grandes realizações, embora não possam ser esquecidas a exploração do petróleo nacional através do monopólio estatal da Petrobras e a expansão da Siderúrgica de Volta Redonda" (SOUTO MAIOR, 1974, p. 344, grifo nosso). Ou ainda na passagem, sobre o governo de Juscelino Kubitschek, do livro didático TDHB Trabalho Dirigido de História do Brasil de Elian Alabi Lucci (1979):

Procurando cumprir o slogan de sua campanha: 'cinquenta anos de progresso em cinco de governo', este Presidente realmente conseguiu promover um intenso desenvolvimento econômico, por meio da aplicação do Plano de Metas, apesar dos aspectos negativos representados pela inflação e elevação do custo de vida (LUCCl, 1979, p. 227).

A ideia de progresso tem uma função ideológica. Se a história tem um sentido - aquele trilhado pelos países centrais do sistema-mundo - bastaria seguir esse caminho que "tudo iria ficar bem no final". Não eram necessárias ações redistributivas ou precaução com os efeitos deletérios do processo, pois todos alcançariam o bem-estar "naturalmente". O otimismo cego marcava o material didático então produzido. ${ }^{2}$

Le Goff lembra, ao narrar a história da ideia de progresso, o quanto essa noção é histórica e contingente. Partindo da compreensão de que o progresso "é um conceito eminentemente ocidental", e que "implica, por um lado, [...] um objetivo ou, pelo menos, uma direção e, por outro, tal finalidade implica um juízo de valor" (LE GOFF, 1996, p. 234). A noção de um progresso técnico contínuo foi durante muito tempo quase impensável. A Era Moderna e o lluminismo trouxeram tal novidade, e o século XIX consagrou a noção de que o progresso técnico não era apenas contínuo, mas que também levaria a um progresso social e moral dos seres humanos. A noção de progresso sempre suscitou reações. $O$ citado autor assinala que mesmo filósofos associados à ideia de progresso como Augusto Conte, não acreditavam em um processo permanente e acelerado de progresso tecnológico. Contudo, na primeira metade do século XX, a Grande Crise de 1929 e as duas Guerras Mundiais levaram a um questionamento profundo da noção de progresso. Os economistas, procurando um discurso mais "científico", passaram a falar em crescimento econômico 
e, posteriormente, elaboraram o conceito de desenvolvimento econômico que não seria necessário e nem reduzido ao mero crescimento do montante da economia, mas implicaria mudanças mais gerais como o aumento da expectativa de vida e escolaridade. Le Goff (1996) chama a atenção para a genealogia do conceito e como progresso e desenvolvimento têm uma continuidade, de forma que não é estranho que, no uso no senso comum, ambos continuem a ter um "sentido para a história" e esse sentido ser positivo.

O crescimento econômico acelerado no centro do sistema-mundo após a Segunda Guerra Mundial jogou para segundo plano a crítica intelectual à noção de progresso. Em 1974, Armando Souto Maior (1974, p. 355) afirma em seu texto didático:

[...] apesar da inflação e dos graves erros cometidos, o Brasil já
ultrapassou a etapa mais difícil de seu processo de industrialização.
Venceu a resistência de espíritos retrógrados e, apesar dos
obstáculos a superar, caminha firme e decididamente rumo à
maturidade industrial. Ainda neste século será uma grande potência
econômica.

A industrialização enquanto progresso e enquanto "projeto nacional" hegemônico marca o pensamento intelectual brasileiro. Seguir o modelo dado pelo centro do sistema- mundo é a marca dos países periféricos (PÁDUA, 1987). Poderia ser um capitalismo liberal, um capitalismo nacional ou, ainda, para alguns, algo parecido com o sistema soviético. De todas as formas, o sentido da história estava dado e ele era positivo: a industrialização.

\section{A industrialização, dependência e conflitos de classe}

O golpe civil-militar de 1964 e o regime não democrático que durou até 1985 tiveram grande peso na não renovação do ensino de história, por impedirem o desenvolvimento de interpretações mais críticas em virtude da censura. Os autores de livros didáticos produzidos no citado período tinham muito claro que, se fugissem da intepretação oficial da história, por exemplo, se não chamassem o golpe de 1964 de "Revolução", estariam sujeitos a processo. E um processo sob a "Lei de Segurança Nacional" poderia implicar em tortura e às vezes na morte do investigado nos "porões da ditadura". Desta forma, havia uma autocensura por parte dos autores (GATTI JÚNIOR, 2007, p. 79). Contudo, as interpretações marxistas da história adquiriram grande prestígio, não apenas por estarem em voga nas universidades, mas porque eram identificadas com uma postura de oposição ao regime ditatorial vigente, em especial com o processo de abertura do regime.

É importante se considerar que, para a indústria editorial, "o que importa não é a ideologia contida no livro e sim sua aceitação no mercado" (MUNAKATA, 1994, p. 20). E a indústria é extremamente ciosa em atender as demandas do mercado. A popularidade dos livros didáticos baseados em perguntas e respostas, pautados mais na memorização de fatos e datas do que na reflexão é um exemplo claro disso. Os editores tinham e têm claro que há professores com formação inicial deficitária, com sobrecarga de trabalho, condições de trabalho problemáticas e baixos salários que descartam o uso de um material denso. Ao 
mesmo tempo, as escolas particulares em geral, tendo melhores condições de trabalho e salário, procuraram, ao longo das décadas de 1980 e 1990, livros didáticos mais densos, mais críticos, pois desejavam que seus alunos passassem no concurso vestibular, e contavam com professores mais preparados para abordar concepções críticas de história. Desta forma, segundo Gatti Júnior (2007, p. 237):

[...] o consumo de livros didáticos apresentava uma diferenciação importante, com o uso de livros considerados mais densos e reflexivos pelos professores das escolas de elite e dos livros de conteúdo mais simples e, por vezes, mais vinculados à memorização, empregados, pelos professores das escolas que atendiam as classes populares.

Nesse período, há uma grande mudança nas perspectivas teóricas que informavam os livros didáticos. A história factual e voluntarista, narrada a partir da perspectiva dos vencedores, é superada por uma história social que busca narrar a história como produto da ação de todos os seres humanos e não apenas das elites políticas e intelectuais (GATTI JÚNIOR, 2007, p. 19).

Um ponto de inflexão marcante neste processo, no que tange a livros didáticos de história do Brasil, foi o lançamento, em 1979, do livro História da Sociedade Brasileira de Francisco de Alencar e Lucia Carp. ${ }^{3}$ Livro de inspiração marxista voltado para o então Segundo Grau, apesar de fazer uso de charges e outros recursos imagéticos é centrado em um texto denso e acadêmico, pouco adequado para o público geral do Ensino Médio brasileiro. Todavia, sua perspectiva crítica de história era inovadora no mercado de livros didáticos de história do Brasil daquele momento.

O discurso nacionalista homogeneizador e silenciador das diferenças é rompido pela lente interpretativa de classe que identifica, na burguesia, os detentores dos meios de produção e, no proletariado, os sujeitos privilegiados da história contemporânea.

Talvez, pela densidade do seu texto, o livro História da Sociedade Brasileira consegue apresentar a mais profunda crítica ao processo de industrialização em meio aos livros publicados entre 1979 e a década de 1990. Por exemplo, no citado livro é afirmado sobre o governo de Juscelino Kubitschek de Oliveira - JK (1956-1961):

Prenunciado nos discursos do candidato, o clima reinante nos primeiros anos de Governo era de entusiasmo e confiança ilimitada na 'aspiração social nova', para a qual todo sacrifício deve ser 'encarado como uma espécie de redenção'. A industrialização era apresentada, tal e qual nos anos 30 , como a chave da emancipação de todos e a conquista do bem-estar geral. Brasília, a nova capital, cuja construção JK audaciosamente iniciou, representava o 'sinal dos novos tempos', apontando para 'um novo Brasil', 'uma nova maneira de ser'.

Presente nos discursos de Juscelino e nos principais documentos do Governo, a ideologia desenvolvimentista teria grande influência na história política do país. Não só funcionou como poderoso instrumento dos interesses industriais contra os agrários tradicionais, como, durante muito tempo, influenciou grande parte das análises sobre a sociedade brasileira. 
Segundo os ideólogos do desenvolvimentismo, o atraso e a pobreza do país deviam-se sobretudo à ainda forte participação do setor agroexportador na economia brasileira, e não à situação de dependência econômica e política a que estava submetida a própria indústria. Em consequência - deduziam - bastava industrializar o país para ressorver todos os seus grandes problemas. Em segundo lugar, em vez de reformas econômicas e políticas reclamadas por alguns setores da sociedade, os países 'subdesenvolvidos' como o Brasil deveriam estreitar a sua integração ao sistema capitalista internacional para 'recuperar o tempo perdido'. Por fim, a industrialização deveria representar o 'esforço comum de toda a Nação'. (ALENCAR; CARPI, 1979, p. 302-303, grifo nosso).

De tal modo que desenvolvimentismo é definido como uma ideologia, como a maneira de pensar e perceber o mundo da burguesia, que justifica sua condição de classe dominante (GUARESCHI, 2000, p. 42). Uma forma parcial de ver a realidade que silencia o fato de que: "Todo esse desenvolvimento, evidentemente, não se processou sem traumas" (ALENCAR; CARPI, 1979, p. 305, grifo nosso). Os livros didáticos de inspiração marxista passaram a explicar esses "traumas" do processo de industrialização, fundamentalmente as implicações sociais como a exploração do trabalho, a miséria, etc.

A geração de livros supracitada pensava o Brasil a partir da chave de interpretação da teoria da dependência. De forma que a industrialização não é mais colocada como "redenção", pois ela, por si, não resolveria a desigualdade interna de classe e a externa da dependência em relação ao centro do sistema-mundo capitalista. Ou nas palavras dos autores citados: "o desenvolvimento não livrava o país da dependência externa. Na realidade, ele recriava novas formas enquanto eliminava outras" (ALENCAR; CARPI, 1979, p. 304, grifo do autor). Entretanto, a industrialização continua a ser desejada, positivada e um passo necessário para o "progresso". Os autores citados compartilham o pensamento hegemônico no Brasil desde a década de 1930, de forma que em História da Sociedade Brasileira citam uma fala de Getúlio Vargas, com a qual sua narrativa da história do Brasil acaba por concordar por mais que critiquem o governo Vargas - a saber:

Ferro, carvão e petróleo [...] são os esteios da emancipação econômica de qualquer país [...] Mesmo os mais empedernidos conservadores agraristas compreendem que não é possivel depender da importação de máquinas e ferramentas, quando uma enxada, esse indispensável e primitivo instrumento agrário, custa ao lavrador 30 cruzeiros, ou seja, na base do salário comum, uma semana de trabalho (GETÚLIO VARGAS apud ALENCAR; CARPI, 1979, p. 267-268, grifo nosso).

A crítica recaía sobre a desigualdade na distribuição da riqueza gerada no processo de industrialização e não na tragédia gerada na vida dos que vivenciaram o processo ou nas implicações socioambientais do processo. A industrialização ainda era compreendida como um bem em si, a forma como ela se dava é que era criticada. O processo de industrialização ainda era a "redenção" para o "atraso", ou seja, a parte não industrializada da sociedade é que continuava a ser estigmatizada, como, por exemplo, no excerto que se segue do livro supracitado: "70\% da população ainda se concentrava no campo, principal- 
mente em áreas produtivas estagnadas e miseráveis" (ALENCAR; CARPI, 1979, p. 228).

Embora a Teoria Crítica e o Ecomarxismo tenham contribuído e contribuam para a teoria social em sua busca por compreender os problemas ambientais contemporâneos, Marx é um autor do século XIX fortemente influenciado pela ideia de progresso. Segundo Bruseke, o citado autor está preso à ideia de que o "[...] progresso social estaria necessariamente ligado ao avanço técnico, avaliação que impossibilitava consequentemente o desenvolvimento de uma crítica das forças produtivas" (BRUSEKE, 2001, p. 116).

Outros livros que foram produzidos neste período adotaram fortemente uma perspectiva marxista caiopradiana, em que o "sentido" da história do Brasil era produzir para a exportação de bens primários (PRADO JÚNIOR, 1994). Nessa perspectiva, o processo de industrialização recebe muita atenção na narrativa dos livros escolares, pois significava um bem-vindo rompimento de tal tendência de produção de bens primários para exportação.

A industrialização era tida como um "progresso", como algo positivo: "Os governos pós-64 têm apresentado, como resultado positivo da opção de desenvolvimento feito pelos autores da modificação política, a realização de um expressivo crescimento econômico, que pode ser demonstrado através de uma série de dados estatísticos" (NADAl; NEVES, 1982, p. 250, grifo nosso).

Mesmo ao abordar o período colonial, a positividade da industrialização é sempre inconteste:

\begin{abstract}
Durante toda a fase colonial e no decorrer do Império, difundiu-se a ideologia de que o Brasil era um país de vocação exclusivamente agrária. No período colonial, as manufaturas têxteis foram proibidas (1785) porque contrariavam os interesses da Metrópole; no período do Brasil Reino Unido e após 1822, a industrialização de nosso país não pode se desenvolver porque contrariava os interesses das potências capitalistas da época, notadamente a Inglaterra. Por isso, o País foi forçado a manter-se como um simples produtor de gêneros agrícolas tropicais e consumidor de produtos industrializados vindos do exterior (COTRIM, 1983, p. 138, grifo nosso).
\end{abstract}

Outro exemplo é o excerto sobre a industrialização no periodo de governo de JK, pois critica os meios, mas não os fins:

Contudo, é preciso salientar que esse progresso ocorreu [...] com amplas e vantajosas concessões aos interesses dos grupos estrangeiros que tivessem capitais aplicados no Brasil. Assim, a fase desenvolvimentista representou um estágio fundamental para a internacionalização da economia brasileira (NADAI; NEVES, 1996, p. 189, grifo nosso).

O próprio conceito de subdesenvolvimento presente nas obras apontava para um sentido a ser percorrido pela história, o da industrialização, seguindo o caminho das "nações mais adiantadas, [...] [como] a Inglaterra [...]" (NADAl; NEVES, 1996, p. 189). Apontando um caminho a ser seguido do subdesenvolvimento ao desenvolvimento, do negativo ao positivo, ou seja, de progresso. 
Tal interpretação econômico-social estava de acordo com as interpretações historiográficas então hegemônicas. É a vaga de estudos culturais que, no Brasil, a partir da década de 1980, vai chamar a atenção para outras dimensões que estavam presentes no processo de industrialização.

Um desses autores, em termos de América Latina, é Arturo Escobar, para quem o "discurso do desenvolvimento" emergiu com o final da Segunda Guerra Mundial. Conforme um novo "regime de representação", o mundo foi dividido entre países desenvolvidos e subdesenvolvidos, definindo grande parte da América Latina, Ásia e África como Terceiro Mundo e propondo a transformação total das suas culturas, formações sociais e ecossistemas, nos moldes dos países intitulados de Primeiro Mundo. Nesse discurso, as filosofias ancestrais deveriam ser eliminadas, os arranjos sociais tradicionais desintegrados, pois esse seria o preço a pagar pelo "benévolo" progresso econômico (ESCOBAR, 2007). Para além do citado "regime de representação", que Escobar denomina desenvolvimentista, os projetos de modernização foram pródigos em justificar a violência praticada em seu nome. Era o "custo humano" do processo de modernização, de industrialização e, tal como o Fausto, de Goethe, publicado no início do século XIX, os modernizadores tinham que "fingir" que não estavam vendo o referido "custo". Na obra, Fausto, o fomentador, como capitão de indústria, pretende comprar uma pequena porção de terra de um velho casal para construir uma torre de observação, com o intuito de contemplar sua obra industrial. Porém, o casal não aceita vender a terra e Fausto ordena que Mefisto e alguns "homens fortes" retirem a dupla do caminho. No entanto, quando Fausto toma conhecimento de que o casal foi morto, fica ultrajado. No caso, evidencia-se uma típica maldade moderna, uma maldade indireta, uma maldade burocrática, para a qual não há responsáveis, todos são instrumentos. Como afirma Berman (1986, p. 67): “Fausto vinha fingindo não só para os outros, mas para si mesmo, que podia criar um novo mundo com mãos limpas; ele ainda não estava preparado para aceitar a responsabilidade sobre a morte e o sofrimento humano que abrem o caminho". Eis aqui o conteúdo trágico da obra de Goethe:

Para compreender a tragédia do fomentador, é preciso julgar sua
visão de mundo, não só pelo que ela revela - pelos imensos novos
horizontes que abre para a espécie humana --, mas também pelo
que ela esconde: pelas realidades humanas que se recusa a ver, pelas
potencialidades que não é capaz de enfrentar. Fausto vislumbra a
luta para criar um mundo onde crescimento pessoal e progresso
social possam ser atingidos com um mínimo de sacrifícios humanos.
Ironicamente, sua tragédia decorre exatamente de seu desejo de
eliminar a tragédia da vida (BERMAN, 1986, p. 66-67).

Apenas na década de 1990 haverá entre os historiadores brasileiros a conclamação para que, nos livros didáticos, os elementos não humanos apareçam como atores de tal "tragédia" (SOFFIATI, 1990). Apesar do mundo natural não estar ausente dos livros de história, pois: "A 'corporação' dos historiadores participou e participa dos investimentos simbólicos para entender, de determinadas formas, os ambientes e os seres humanos, contribuindo para legitimar a apropriação de alguns ou a expropriação de outros" (CARVALHO, 2014, 
p. 179). Há um grande silenciamento nos livros analisados sobre os efeitos negativos para os elementos não humanos do processo de industrialização no Brasil.

Um bom exemplo do citado silenciamento é a apropriação que Elza Nadai e Joana Neves fazem em seu livro História do Brasil do trabalho de Celso Furtado:

Celso Furtado, em seu livro O mito do desenvolvimento econômico, coloca: [...] o quadro estrutural presente do sistema capitalista, vemos que o processo de acumulação tende a ampliar o fosso entre um centro, em crescente homogeneização, e uma constelação de economias periféricas, cujas disparidades continuam a agravar-se. [...]

Temos assim a prova definitiva de que o desenvolvimento econômico - a ideia de que os povos pobres podem algum dia desfrutar das formas de vida dos atuais povos ricos - é simplesmente irrealizável. [...]

Cabe, portanto, afirmar que a ideia de desenvolvimento econômico é um simples mito. Graças a ela tem sido possível desviar as atenções da tarefa básica de identificação das necessidades fundamentais da coletividade e das possibilidades que abre ao homem o avanço da ciência, para concentrá-los em objetivos abstratos como são os investimentos, as exportações e o crescimento. A importância principal do modelo de The Limits to Growth é haver contribuido, para destruir esse mito, seguramente um dos pilares da doutrina que serve de cobertura à dominação dos povos dos países periféricos dentro da nova estrutura do sistema capitalista (NADAl; NEVES, 1996, p. 402, grifo nosso).

O citado trabalho de Furtado é um diálogo com o livro The Limits to Growth (MEADOWS, et al., 1972) que, por sua vez, influenciou a Conferência de Estocolmo de 1972. As autoras do livro didático se limitam a explicar a crítica de Furtado aos Limites do Crescimento, pois o cenário de futuro previsto pelos autores pressupunha uma universalização do padrão de consumo dos países centrais do sistema; enquanto Furtado postulava que a manutenção e ampliação do fosso entre países pobres e ricos seria um cenário mais plausível. Embora Furtado dialogue amplamente com a ideia de que os "recursos naturais" são limitados e que a produção ilimitada de bens está em choque com a terceira lei da termodinâmica. Ou seja: matéria e energia entram no processo produtivo em um estado de baixa entropia e saem em um estado de alta entropia. Logo, considerando o limite de recursos e a dispersão de energia, a inexorável conclusão de Celso Furtado, ainda no início da década de 1970, era de que desenvolvimento econômico é um mito, "um conjunto de valores e pressupostos indemonstráveis que orientam a ação" - "rumo à distopia do crescimento econômico ilimitado" (FURTADO, 1974, p. 14).

No livro didático, contudo, tais aspectos ecológicos não são debatidos. E a ênfase ainda é dada às "possibilidades que abre ao homem o avanço da ciência" (NADAl; NEVES, 1996, p. 402). Ademais, o comentário ao texto de Celso Furtado está no livro didático, supracitado, em um box, na margem da página que versa sobre "A Abertura Política e o Fim da Ditadura". O fato de não estar no texto principal é uma característica importante como será observado adiante. Outro exemplo da dificuldade dos historiadores incorporarem a crítica ambiental é o fato de no citado livro didático ter uma foto de Chico Mendes sentado em 
uma mesa com a seguinte legenda: "Chico Mendes, líder seringalista e crítico da ocupação amazônica, foi assassinado em consequência de conflitos sociais na região. Sua morte teve repercussão internacional" (NADAl; NEVES, 1996, p. 417). Não há nenhuma outra menção às implicações socioambientais das atividades ou da morte de Chico Mendes. Como se verá, o silenciamento da problemática ambiental nos livros didáticos de história ainda não foi superada.

\section{Da sociedade de produtores à sociedade de consumidores: A industrialização é uma festa?}

A partir da década de 1990 há uma melhora na qualidade dos livros didáticos produzidos no Brasil e a tentativa de incorporação da educação ambiental em seus conteúdos.

Em 1996, é estabelecido o processo de avaliação pedagógica dos livros comprados pelo governo federal brasileiro, primeiro para os primeiros anos do Ensino Fundamental, depois progressivamente para os demais anos. Em 1999, é realizada a primeira avaliação para os anos finais do Ensino Fundamental de História. Em 2007, o governo federal realizou uma avaliação de livros para o Ensino Médio e produziu um Guia que orientou a escolha dessas publicações pelos professores. Apenas em 2008 o governo federal passou a distribuir gratuitamente livros para o Ensino Médio.

Como o governo federal tornou-se o maior comprador de livros, parte do mercado editorial brasileiro se voltou para atender o negócio bilionário das compras estatais. Equipes pedagógicas foram constituídas nas editoras e os livros são, cada vez mais, uma produção coletiva. Acentuando a tendência do livro didático enquanto mercadoria produzida pela indústria cultural, o papel desempenhado pelo autor individual é cada vez mais reduzido em relação a conjuntos de atores que interferem no processo produtivo: editores, diagramadores, ilustradores, etc. (GATTI JÚNIOR, 2007, p. 236). O resultado do processo de avaliação é que, no século XXI, há uma reversão da tendência das escolas particulares de adotarem um material diferenciado do usado nas escolas públicas, como símbolo de distinção. Ao contrário, as escolas particulares procuram os livros aprovados pelo Guia dos Livros Didáticos do Ministério da Educação, pois são entendidos como uma garantia de qualidade. Mesmo que ainda haja diferença entre a qualidade física do material utilizado em escolas públicas e privadas e, talvez, que as editoras continuem a produzir livros mais densos para escolas com melhores condições de trabalho e qualificação do corpo docente e livros menos densos para escolas que não tenham tais condições, atingindo diferentes nichos de mercado.

Um dos elementos que as editoras buscam atender para serem aprovados e elogiados nos processos avaliativos é a educação ambiental. Em tese, segundo o artigo 255 da Constituição Brasileira de 1988, ao Poder Público incumbe promover a educação ambiental em todos os níveis de ensino, e despertar a consciência pública para a preservação do meio ambiente. Além disso, com a promulgação da Lei de Diretrizes e Bases da Educação (LDB), 
Lei no 9.394/96, a inserção da temática ambiental ao ensino formal foi regulamentada pelos Parâmetros Curriculares Nacionais, por meio do qual, o meio ambiente passou a ser tratado como "tema transversal" (GERHARDT; NODARI, 2010, p. 57-72). Ademais, a Política Nacional de Educação Ambiental, Lei no 9.795, de 27 de abril de 1999, estabeleceu em seu artigo 10 que: "A educação ambiental será desenvolvida como prática educativa integrada, contínua e permanente em todos os níveis e modalidades de ensino formal". Estabelecendo, assim, não mais apenas o direito à educação ambiental, mas a obrigação de haver educação ambiental. Sendo que, no parágrafo primeiro do citado artigo, consagra o princípio da transversalidade da educação ambiental ao postular que: "A educação ambiental não deve ser implantada como disciplina específica no currículo de ensino" (BRASIL, 1999). Como tais transformações alteram ou não as representações a respeito da industrialização no Brasil?

Crupi (2008, p. 3), ao analisar livros dos anos finais do Ensino Fundamental, afirma que os "resultados do trabalho apontam que a crise socioambiental contemporânea, embora se constitua como grave problema no tempo presente, pouco tem influenciado na seleção e no tratamento dos conteúdos a respeito da relação sociedade-natureza nos livros didáticos de História".

O livro História: das Cavernas ao Terceiro Milênio traz como documento de época o discurso de posse do presidente Luiz Inácio Lula da Silva, em 2002, emblemático de algumas transformações que devem ser assinaladas para entender as representações sobre industrialização. O título da fala é "Um projeto de nação":

O Brasil precisa mudar. Precisa ser planejado a longo prazo. Precisa se unificar em torno de um projeto de nação que beneficie o conjunto do nosso povo e resgate dívidas sociais seculares. Essa é a vontade da grande maioria da população.

[...] O novo modelo não poderá ser produto de decisões unilaterais do governo, tal como ocorre hoje, nem ser implantado por decreto, de modo voluntarista. Será fruto de uma ampla negociação nacional, que deve conduzir a uma autêntica aliança pelo país, a um novo contrato social, capaz de assegurar o crescimento com estabilidade (Luiz Inácio Lula da Silva, 2002 apud MOTA; BRAICK, 2005, p. 200, grifo nosso).

"Crescimento com estabilidade", sequer usa-se o conceito guarda-chuva de "desenvolvimento sustentável". A fala presidencial é clara; em um país com uma história econômica marcada por surtos de crescimento e crises econômicas recorrentes, o desafio era estabilizar um crescimento permanente, quiçá ad infinitum.

Escobar, muito otimistamente, defendeu que estamos em uma era pós-desenvolvimentista, pois a mudança tecnológica essa não é mais percebida como algo que necessariamente implica a dissolução das culturas locais; e, apesar do processo de globalização, não há mais a exigência da homogeneização nos mesmos termos dos anos 1950, quando se inicia o que ele chama de "discurso desenvolvimentista" (ESCOBAR, 2007).

Entretanto, apesar da força do movimento dos povos originários, camponeses, entre outros e de terem ocorrido importantes mudanças rumo a uma reapropriação social da 
natureza (LEFF, 2006). O fato da tecnologia não ser mais vista como um dissolvente da cultura local e da globalização não implicar necessariamente em homogeneização sugere apenas que temos hoje uma economia de escopo, capaz de atender os diferentes nichos de mercado. E que passamos, como afirma Bauman (2005, p. 113), de uma sociedade de produtores para uma sociedade de consumidores.

Na sociedade de consumidores, ninguém pode se tornar sujeito sem primeiro virar mercadoria, e ninguém pode manter seguro sua subjetividade sem reanimar, ressuscitar e recarregar de maneira perpétua as capacidades esperadas e exigidas de uma mercadoria vendável. A 'subjetividade' do 'sujeito', e a maior parte daquilo que essa subjetividade possibilita ao sujeito atingir, concentrase num esforço sem fim para ela própria se tornar, e permanecer, uma mercadoria vendável. A característica mais proeminente da sociedade de consumidores - ainda que cuidadosamente disfarçada e encoberta - é a transformação dos consumidores em mercadorias; ou antes, sua dissolução no mar de mercadorias [...] (BAUMAN, 2005, p. 20).

Vender a si mesmo, a produção de si em um processo de autopoiese enquanto mercadoria vendável. Na sociedade de produtores, o esforço era para produzir um "homem novo", um trabalhador diligente, competente e disciplinado, adequado a uma sociedade industrial, ou seja, em uma modernidade clássica. Na atual modernidade líquida (e pós-industrial), o ato de produzir perde a sua centralidade para o ato de consumo. Mas o crescimento econômico continua a ser o sentido almejado da história. Não se trata mais apenas de colocar "comida na mesa". A venda de si é fundamental para a realização subjetiva como sujeito, mesmo que venha acompanhada de frustrações da pressão permanente da venda de si e de uma sobrecarga em nossos egos (BAUMAN, 2005).

De forma que a industrialização perde espaço nos livros didáticos de história, não apenas porque a história econômica perdeu um grande espaço para a história cultural na academia (FREITAS, 2001), mas porque a indústria (produção) perdeu seu lugar central para o consumo e o desenvolvimento tecnológico em todos os setores (o que alguns sintetizariam como a ideia de "sociedade da informação").

Aqui, o que deve ser destacado é a persistência da representação da industrialização enquanto progresso, mesmo neste novo contexto de crítica ambiental e de uma sociedade de consumidores.

Ao abordar a industrialização brasileira, a lente crítica da desigualdade na distribuição de benefícios está presente e as implicações nos ecossistemas dos processos industriais ganharam espaço, mesmo que de forma fragmentada. Porém, os autores ainda não conseguem superar a noção de progresso, ou ressignificá-lo.

Morin (1999, p. 95) afirma que a ideia tradicional de progresso implica quatro características: 1 - cumulativo, 2 - linear, 3 - quantitativo, 4 - qualitativo. E que a ideia "tradicional de progresso implica ainda em afirmar que ele é racional, ordem e organização". O referido autor argumenta que as próprias pesquisas das ciências da vida e da matéria teriam levado a 
um abandono da citada ideia, pois mostraram que o mundo físico e biológico não seguem tais princípios, que dirá o mundo humano. Sendo que Morin (1999, p. 97-98) nos desafia: "[...] há que fazer um progresso na ideia de progresso, que deve deixar de ser noção linear, simples, segura e irreversível para tornar-se complexa e problemática".

Neste sentido, o livro didático História: volume único afirma:

\begin{abstract}
A partir de 1930, a sociedade brasileira passou por mudanças políticas, reformas sociais, crescimento da economia, surgimento de ideologias de direita e de esquerda e transformações culturais. Mas, com a insurreição comunista de 1935, o governo acumulou cada vez mais poderes e, dois anos depois, instituiu a ditadura do Estado Novo, um regime político autoritário. Para o historiador Boris Fausto, 'o Estado Novo apresenta facetas bem variadas'. O Estado censurou, prendeu, torturou, controlou os sindicatos, mas, ao mesmo tempo, promoveu o desenvolvimento econômico e os melhores nomes da cultura da época. Dessa maneira Boris Fausto formula uma pergunta instigante: 'Que diabo é esse regime que gera essencialmente uma série de males e, ao mesmo tempo, tem facetas de progresso?' [...] É essa dupla dimensão que veremos a seguir (VAINFAS et al., 2010, p. 673).
\end{abstract}

Há uma tentativa aqui de dar conta da ambivalência dos processos de transformação econômicos, sociais e tecnológicos, de forma que eles não sejam entendidos como cumulativos, lineares, quantitativos e qualitativos. Entretanto, apesar da narrativa buscar compreender a ambivalência e a contingência do processo histórico, ainda predomina nos livros didáticos a noção de que a industrialização (ou o crescimento quantitativo da economia) é o sentido (desejado) da história e que tal sentido é positivo.

A industrialização ainda é adjetivada positivamente. $O$ problema é apontado fundamentalmente na distribuição de seus resultados. No seu livro didático, Myriam Becho Mota e Patrícia Ramos Braick (2005) afirmam, sobre o governo JK:

$\mathrm{Na}$ verdade, é preciso considerar que parte dos gastos públicos favoreceu a sociedade como um todo. Nesse rol, incluemse a construção de estradas, a ampliação da rede de energia, os novos produtos industrializados e a construção da nova capital (projeto extremamente oneroso, mas que abriu o caminho para o desenvolvimento da região do Planalto Central) (MOTA; BRAICK, 2005, p. 113, grifo nosso).

Não se esquecendo os autores de demarcar em seu texto que há os "excluídos da festa do desenvolvimento" (MOTA; BRAICK, 2005, p. 136, grifo nosso) e suas lutas. Ou seja, a ambivalência "social" dos processos de industrialização é bastante explorada. A ambivalência "ambiental" dos processos de industrialização é menos destacada. De qualquer forma, os textos não chegam a assumir totalmente a ambivalência do processo de industrialização. Pois há um juízo de valor positivo a respeito da industrialização. A ironia em afirmar que a industrialização é uma festa está na exclusão da maioria da população, mas a tragédia da ironia está no fato da industrialização continuar a ser representada como uma "festa", como algo positivo. 
De maneira que em História: das Cavernas ao Terceiro Milênio os autores afirmam, sobre o regime autoritário iniciado em 1964, que: "Inicialmente, a nova política econômica trouxe resultados positivos, uma vez que o PIB (Produto Interno Bruto) alcançou um índice de crescimento entre 10 e 11,2\%. Iniciava-se então o período que ficou conhecido como 'milagre econômico brasileiro'" (MOTA; BRAICK, 2005, p. 159, grifo nosso).

Explicando que os "resultados positivos" dos governos militares serviram para legitimar o regime autoritário (MOTA; BRAICK, 2005, p. 168) e, por mais que o texto tenha uma perspectiva crítica do tipo de crescimento econômico, uma mensagem é perpetuada: crescimento econômico é algo positivo. Desta forma, o citado livro didático afirma sobre o "Governo Ernesto Geisel (1974-1979)" que: "O plano deu bons resultados: os índices de crescimento econômico de fato assinalavam uma alta expressiva" (MOTA; BRAICK, 2005, p. 163, grifo nosso). E História: volume único assevera, sobre o período democrático de 1945 a 1964, que: "Na economia ocorreu uma extraordinária taxa de crescimento particularmente industrial [...] um claro e seguro progresso; na área social, o desenvolvimento foi mais lento" (VAINFAS et al., 2010, p. 775, grifo nosso).

O referido livro afirma, ainda, que: "O Brasil passou a ter uma nova capital, Brasília. Oscar Niemeyer e Lucio Costa planejaram uma cidade de arquitetura moderna no interior do Goiás, numa região onde havia apenas a natureza. Essa era a grande meta de JK: Brasília assumiu a condição de Distrito Federal" (VAINFAS et al., 2010, p. 786, grifo nosso).

O não-progresso, o "outro" da industrialização, era a natureza e o "atraso". Assim, em pleno 2010, um lugar ser supostamente "só natureza" (desconsiderando a população local em tal narrativa) ainda é justificativa para a "substituição" pelo "progresso". 4

Assim, nas entrelinhas ainda pode-se ler a industrialização enquanto progresso nos livros didáticos, diante de uma crítica ambiental fragmentada ou inexistente. É esta a representação que contribui para informar o cidadão brasileiro em pleno século XXI.

\section{A dificuldade de compreensão da ambivalência da industrialização em uma narrativa de progresso}

O limite da incorporação de uma crítica ambiental na narrativa escolar da história continua bastante presente.

Nos livros hegemônicos na década de 1970, até poderia ocasionalmente constar um resultado "problemático" da industrialização. Como na seguinte legenda de História do Brasil:

São Paulo na década de 70. O fenômeno do urbanismo, além de sérios problemas sociais, deu-nos também o problema da poluição do ar que respiramos. Em 1966 a Prefeitura de São Paulo constatou que a capital paulista tinha um índice de poluição quase igual ao de Tóquio, o mais alto do mundo (SOUTO MAIOR, 1974, p. 356). 
A ideia presente no livro de que "tudo ficaria bem no final", graças ao progresso minimiza, quando não silencia, tais implicações deletérias.

O inovador livro História da Sociedade Brasileira, de 1979, já apontava a dificuldade de incorporar as ambivalências socioambientais nas narrativas didáticas do processo de industrialização. Apesar do silenciamento sobre as implicações deletérias, dominante até então, ser rompido na citada obra, como segue:

A correção monetária não reduziu a inflação; [...] a modernização da agricultura, além de insuficiente, gerou novos problemas, devido à forma como foi feita, expulsão de posseiros, invasão de reservas indígenas, crescimento do 'exército' de boias-frias na periferia das cidades do interior e crise crônica no abastecimento de certos produtos essenciais (como o feijão), prejudicados em sua produção pela ênfase dada às lavouras de exportação. Somase a isso o desmatamento indiscriminado, gerando indiretamente até fenômenos climáticos, como a seca no sul do país (ALENCAR; CARPI, 1979, p. 228, grifo nosso).

Todavia, as questões socioambientais são simplesmente citadas em um inventário dos "traumas" trazidos pela industrialização. O máximo que se pode esperar da geração de livros que se seguiram a História da Sociedade Brasileira são pequenas inserções no texto sobre implicações socioambientais da industrialização. Já os livros do século XXI tendem a procurar "acomodar" a temática "ambiental" e a exigência da presença da educação ambiental. Por exemplo, no livro História, de 2010, aparece uma foto de Chico Mendes na floresta extraindo látex de uma árvore e a seguinte legenda: "O crime de maior repercussão mundial foi o assassinato do presidente do Sindicato dos Trabalhadores Rurais e ativista da defesa ambiental, Chico Mendes, em dezembro de 1988, no quintal de sua casa na cidade de Xapuri, Estado do Acre" (VAINFAS et al., 2010, p. 849, grifo nosso).

Abordar questões "ambientais" em livros de história continua a ser um desafio para autores e toda a equipe técnica, sendo comum a inserção de elementos isolados sem uma contextualização que leve a reflexões mais profundas. Soares e Novicki (2006) já haviam constatado a incorporação do tema meio ambiente - enquanto tema transversal - nos livros didáticos de História, dos anos finais do Ensino Fundamental, no acréscimo de quadros (box) separados do conteúdo principal, apenas para tentar atender a obrigação legal da presença do tema, sem a proposta de uma reflexão sobre a questão ambiental.

Quando encontramos um raciocínio mais consistente a respeito da relação entre industrialização (no caso no período do Regime ditatorial pós-1964) este está em um box, como a citação do texto de outro autor:

O 'capitalismo selvagem' caracterizou aqueles anos e os seguintes, com seus imensos projetos que não consideravam nem a natureza nem as populações locais. A palavra 'ecologia' mal entrara nos dicionários e a poluição industrial e dos automóveis parecia uma bênção. No governo Médici, o projeto da Rodovia Transamazônica representou um bom exemplo desse espírito. Ela foi construída para assegurar o controle brasileiro da região - um eterno fantasma na óptica dos militares - e para assentar em agrovilas trabalhadores 
nordestinos. Após provocar muita destruição e engordar as empreiteiras, a obra resultou em fracasso (FAUSTO, 1995 apud MOTA; BRAICK, 2005, p. 168).

Contudo, nos livros didáticos do século XXI a questão ambiental tende a ganhar o corpo do texto. Em História: volume único, na parte destinada à "história geral" há a afirmação:

O mundo chegou ao fim do século XX sob a liderança econômica, política e militar dos Estados Unidos. Nos últimos anos do século, o capitalismo experimentou fase de grande expansão que provocou a aceleração do processo conhecido como globalização. O século XXI parecia ser muito promissor. No entanto, ataques terroristas, novas guerras e grave crise econômica levaram sofrimento a milhões de pessoas em todo o mundo. Mas algo de positivo desponta no novo século: aumentou a consciência ambientalista e a convicção de que a catástrofe ecológica, se ocorrer, poderá destruir a humanidade. Apesar de tudo, muitos acreditam que a humanidade pode superar suas dificuldades criando formas de convivência baseadas nos direitos dos cidadãos e na democracia, alcançando a paz entre os povos (VAINFAS et al., 2010, p. 877, grifo nosso).

Mas, tal "catástrofe que poderá destruir a humanidade" é explicada apenas em um tópico intitulado "Aquecimento global: o planeta em perigo" (VAINFAS et al., 2010, p. 889). O livro História Geral: Brasil e Geral, de Gilberto Cotrim (2012), segue um caminho similar. ${ }^{5} \mathrm{O}$ tópico intitulado "Crise ambiental", na parte sobre "história geral", explica:

Outro problema que pode ser vinculado à expansão do capitalismo e à globalização econômica é a crise ambiental que ameaça a sobrevivência do planeta e da humanidade.

Um dos principais problemas apontados nesse sentido é o fenômeno de mudança climática conhecido como aquecimento global. Cientistas calculam que as temperaturas médias superficiais do planeta vêm aumentando nos últimos 150 anos, período correspondente ao da Revolução Industrial.

$\mathrm{Na}$ opinião de muitos especialistas, os países desenvolvidos (suas populações, empresas e governos) são os maiores responsáveis pela deterioração ambiental, sobretudo os Estados Unidos, por sua produção, seu consumismo e o modelo econômico que implementaram e impõem. No entanto, esses mesmos especialistas alertam para o fato de que a situação está se agravando com a ascensão das economias de países emergentes, principalmente China e Índia, que entraram com muita força no mercado globalizado. Esses países já estão gerando grande impacto ambiental, pois apresentam, juntos, uma população de 2,5 bilhões de pessoas, que começou a adotar os mesmos hábitos de consumo do mundo ocidental, além do costume de poluir.

Assim, o problema, que já é grande, pode se tornar bem maior: se mais nações passarem a produzir e consumir com a mesma intensidade das nações desenvolvidas, o mundo entrará em colapso rapidamente, conforme advertem cientistas e pessoas de bom-senso (COTRIM, 2012, p. 654-655, grifo nosso).

No livro didático de Ronaldo Vainfas et al. (2010), há uma perspectiva otimista a respeito do aquecimento global que é apontado como um perigo, mas com uma possível solução no horizonte. No livro de Gilberto Cotrim (2012), por sua vez, o aquecimento global é tratado com mais pessimismo, pois apresenta uma situação potencialmente perigosa para 
a sobrevivência da humanidade colocada como problema para o aluno pensar.

Não é o escopo deste artigo entrar na controvérsia sobre o aquecimento global. Mas, é necessário chamar a atenção para a redução brutal da problemática ambiental, restringida ao aquecimento global, uma simplificação de nossa atual crise civilizatória (LEFF, 2006).

A situação dos livros didáticos brasileiros não é exceção no cenário internacional. Nos Estados Unidos, por exemplo, Ward, em trabalho de 2006, analisou livros didáticos publicados entre 1794-1999 sobre História dos Estados Unidos e constatou que os "conceitos de modernização, progresso e industrialização figuram proeminentes na maioria dos livros de história dos EUA, escritos ao longo dos últimos cem anos" (WARD, 2006, p. 217). Sendo que, enquanto muitos textos apontam apenas os aspectos positivos da industrialização, outros apontam os aspectos negativos, como a pobreza e a imigração, como um contraponto (WARD, 2006, p. 217). Todavia, em pleno 2006, no citado texto, Ward não menciona as questões ambientais entre os elementos de "contraponto" às benesses da industrialização.

Loewen, na segunda edição, de 2007, do seu Lies my teacher told me: Everything your American History Textbook got wrong, atualiza a análise feita orginalmente em 1995, e se pergunta por que os livros da história dos Estados Unidos têm um tratamento tão falho de temas ambientais. Para o citado autor, a noção de progresso tem um papel central para explicar a referida falha, afirmando que a ideia de progresso é conservadora na sociedade estadunidense. Afinal, se tudo vai melhorar no futuro, não é necessário fazer mudança social alguma. Se todos podem prosperar e enriquecer não são necessárias políticas redistributivas. $O$ autor salienta, ainda, que os livros didáticos sobre história dos Estados Unidos são uma celebração nacionalista e a noção de progresso legitima tal celebração, pois "tudo ficará bem no final" (LOEWEN, 2007, p. 295).

Loewen chama a atenção para a ausência do debate sobre o aquecimento global nos livros didáticos contemporâneos de história dos Estados Unidos. E aponta como exceção o livro didático The American Pageant, que menciona, ao final da obra, sobre o tema do aquecimento nos seguintes termos: que o mundo hoje é reconhecido como um grande ecossistema que estaria ameaçado pelo aquecimento global; que o perigo vai além das fronteiras nacionais; e que os americanos orgulhosamente fazem um esforço para limpar seu próprio território, para poderem dizer aos brasileiros que eles não devem cortar a floresta tropical (LOEWEN, 2007, p. 294). De fato, o livro didático estadunidense silencia sobre a grande injustiça ambiental presente nos padrões de produção, consumo e trocas internacionais, nos quais $20 \%$ da população mais rica são responsáveis por algo em torno de $80 \%$ do consumo e da poluição. Sendo a citada minoria a responsável pela sobre-exploração da ecosfera. Ao passo que, para chegarmos a uma justiça ambiental, algo em torno de $20 \%$ a $60 \%$ dos mais pobres poderiam aumentar sua parcela de consumo, visando sanar uma "dívida social" e alcançar uma sustentabilidade social (PÁDUA, 2005).

Não cabe aqui aprofundar a crítica à iniquidade socioambiental internacional, mas chamar a atenção para o fato de que, apesar da narrativa da história do Brasil ainda estar 
presa a uma noção de progresso, a crítica ambiental presente nos livros de história do Brasil são mais consistentes do que as presentes nos livros de história dos EUA, a julgar pelos trabalhos abordados. ${ }^{6}$ Por exemplo, o livro didático estadunidense comentado anteriormente apresenta os EUA como modelo a ser seguido, pois "orgulhosamente" limpariam seu território para "falar" aos brasileiros para não cortar a floresta tropical (LOEWEN, 2007, p. 294). Reproduzindo o mito do destino manifesto dos EUA de conduzir o mundo à "salvação", e também a ideia de que o centro do sistema-mundo é o modelo a ser seguido. Loewen (2007, p. 288) critica a segunda postura, ao afirmar que, economicamente, só podemos torcer para que outras nações nunca alcancem o padrão de vida médio estadunidense, pois se o fizessem, a terra se tornaria um "deserto". Tal questão já está presente nos livros didáticos brasileiros, por exemplo, no já mencionado excerto: "se mais nações passarem a produzir e consumir com a mesma intensidade das nações desenvolvidas, o mundo entrará em colapso rapidamente" (COTRIM, 2012, p. 654-655). Todavia, o tema é tratado de forma superficial, como indica o fato de chamar a poluição de "costume" (COTRIM, 2012, p. 654-655) e não como algo estrutural do sistema industrial. E o tema "meio ambiente" não é estruturante da narrativa histórica, como argumentado, ele ainda é inserido de maneira mais ou menos pontual, em grande parte por força da legislação e dos processos avaliativos dos livros didáticos. De forma que a afirmação supra de Loewen (2007) pode ser aplicada ao caso brasileiro: a persistência de uma narrativa de progresso tende a dificultar a compreensão da problemática ambiental.

\section{Considerações Finais}

Mais que a descontinuidade, o presente trabalho quer chamar a atenção para a continuidade da industrialização enquanto progresso. Se em um primeiro momento, na década de 1970, ela era representada como a "redenção", a renovação historiográfica e a abertura política dos anos 1980 introduzem uma perspectiva crítica na qual a desigualdade do processo de industrialização é explorada nos livros didáticos. As implicações deletérias aos ecossistemas e os problemas socioambientais, durante muitos anos silenciados nas narrativas históricas, começam a aparecer na narrativa central dos livros de história apenas no século XXI.

Todavia, a orientação histórica que se aduz nos livros didáticos é ainda a ideia de que a industrialização é uma "festa". Ou seja, o crescimento econômico ainda é apresentado como algo que pode ser medido pelo crescimento do PIB, sendo um sentido positivado da história. Colácios analisa a noção de progresso em livros didáticos dos anos finais do Ensino Fundamental, publicados entre 1995 e 2002. Ao abordar o lluminismo, assevera que não há uma diferenciação entre progresso tecnológico, social e moral. Para o autor, não há nos livros e temática por ele analisados, elementos suficientes para entender a historicidade da noção de progresso, o que acaba por contribuir para a reprodução do senso comum (COLÁCIOS, 2011). Assim, estamos longe de "superar a ideologia convencional do desenvolvimento em favor de um debate ético-político sobre o desenvolvimento en- 
quanto direito das sociedades à melhoria das suas condições de vida em um contexto de equidade e sustentabilidade planetárias" (PÁDUA, 2005, p. 189).

Obviamente um livro didático obrigatoriamente tem que esquematizar as informações e interpretações e passar por um processo de seleção de conteúdo. Há sempre coisas que serão esquecidas para que outras sejam lembradas. E tal jogo não é uma decisão arbitrária dos autores: há um currículo canônico estabelecido pela tradição de estudos; há os currículos estaduais e os PCNs; há a pressão de movimentos e diferentes grupos sociais com mais ou menos recursos de poder para estarem presentes nas narrativas. Todas essas e outras linhas de forças estabelecem e balizam quem se propõe a escrever um livro didático.

Ademais, a dificuldade de introduzir o meio ambiente e a educação ambiental como temas transversais deve ser abordada à luz da hegemonia de um:

[...] estilo de pensamento disjuntivo: 1 - que separa natureza dos seres humanos e impede a compreensão da complexidade dos problemas ditos ambientais; 2 - que atribui a algumas disciplinas, como a Geografia por estar associada à natureza, a função de educação ambiental; enquanto retira a responsabilidade e atribuição de outras, como a História que se torna uma disciplina exclusiva para explicar fatores puramente 'sociais'. Tal estilo de pensamento tem mais força em influenciar a produção de livros didáticos para as escolas públicas no Brasil do que a própria legislação brasileira (CARVALHO, 2012, p. 371).

O que este artigo busca apontar é que uma narrativa de progresso é um dos fatores que dificultam a construção de uma narrativa da história do Brasil que incorpore a ambivalência do processo de industrialização e de desenvolvimento econômico.

O papel da história não é preparar o aluno para as certezas trazidas pelo passado, mas contribuir para preparar o cidadão para agir diante das incertezas do futuro. Neste sentido, Edgar Morin, ao discorrer sobre os saberes necessários para a educação do futuro, afirma que: "Os séculos precedentes sempre acreditaram em um futuro, fosse ele repetitivo ou progressivo. O século XX descobriu a perda do futuro, ou seja, sua imprevisibilidade" (MORIN, 2000, p. 79).

Como agir na incerteza? O grande interesse na história enquanto memória é característico de nossa época "presentista", em que tendemos a pensar apenas no presente - em como nos vender enquanto mercadoria - e a história tem pouca função de orientação temporal do dia a dia (HARTOG, 2014).

Produzir uma narrativa histórica escolar sem uma tranquilizadora noção de progresso ou uma assustadora ausência de futuro e que, ao mesmo tempo, contribua para produzir uma solidariedade intergeracional, importante para pensar um futuro sustentável, é o grande desafio ainda presente.

\section{Referências}


ALENCAR, Francisco; CARPI, Lucia. História da Sociedade Brasileira. Rio de Janeiro: Ao Livro Técnico, 1979.

ALMEIDA, Jozimar Paes de. A difusão do conhecimento científico sobre meio ambiente nos livros didáticos de História. História \& Ensino, Londrina, v. 11, p. 75-95, jul. 2005. Disponível em: <http://www.uel.br/revistas/uel/index.php/histensino/article/ download/11839/10408>. Acesso em: 10 jun. 2015.

BARBOSA, Lívia. Garimpo e meio ambiente: águas sagradas e águas profanas. Estudos Históricos, Rio de Janeiro, v. 4, n. 8, p. 229-243, 1991. Disponível em: <http:// bibliotecadigital.fgv.br/ojs/index.php/reh/article/view/2320/1459>. Acesso em: 10 jun. 2015.

BAUMAN, Zygmunt. Vidas para o consumo. Rio de Janeiro: Zahar, 2005.

BERMAN, Marshall. Tudo que é sólido desmancha no ar: A aventura da modernidade. São Paulo: Companhia das Letras, 1986.

BITTENCOURT, Circe Maria Fernandes. Livro didático e conhecimento histórico: uma história do saber escolar. 1993. Tese (Doutorado História) - Faculdade de Filosofia, Letras e Ciências Humanas, Universidade de São Paulo, São Paulo, 1993.

BRASIL. Presidência da República. Casa Civil. Subchefia para Assuntos Jurídicos. Lei no 9.795, de 27 de abril de 1999. Política Nacional de Educação Ambiental. Disponível em: <http://www.planalto.gov.br/ccivil_03/leis/l9795.htm>. Acesso em: 9 mar. 2014.

BRUSEKE, Fraz Josef. A técnica e os riscos da modernidade. Florianópolis: Ed. da UFSC, 2001.

CARVALHO, Ely Bergo de. "A natureza não aparecia nas aulas de História":

lições de educação ambiental aprendidas a partir das memórias de professores de História. História Oral, São Paulo, v. 15, n. 1, p. 357-379, jan./jun. 2012. Disponível em: <http://revista.historiaoral.org.br/index. php? journal=rho\&page $=$ article\&op=view\&path\%5B\%5D =244\&path\%5B\%5D =279>. Acesso em: 10 jun. 2015.

CARVALHO, Ely Bergo de. No fundo da Mata Virgem: a complexidade de um elemento mítico no imaginário ocidental sobre a natureza. Tempo e Argumento, Florianópolis, v. 2, n. 2, p. 135-153, jul./dez. 2010. Disponível em: <http://periodicos.udesc.br/index.php/ tempo/article/view/2039/1613>. Acesso em: 22 fev. 2011.

CARVALHO, Ely Bergo de. Uma História a serviço da destruição? Livros de História e a modernização de Mato Grosso, Brasil, 1964-1992. HALAC Historia Ambiental 
Latinoamericana y Caribeña, Belo Horizonte, v. 3, n. 1, p. 155-179, set. 2013 fev. 2014. Disponivel em: <http://www.fafich.ufmg.br/halac/index.php/periodico/article/ viewFile/100/116>. Acesso em: 30 set. 2013.

CHARTIER, Roger. À Beira da Falésia: A História entre certezas e inquietude. Porto Alegre: Editora da UFRGS, 2002.

CHERVEL, André. História das disciplinas escolares. Teoria e Educação, Porto Alegre, n. 2, p. 177-229, 1990.

CHOPPIN, Alain. História dos livros e das edições didáticas: sobre o estado da arte. Educação e Pesquisa, São Paulo, v. 30, n. 3, p. 549-566, set./dez. 2004. Disponível em: <http://www.scielo.br/pdf/ep/v30n3/a12v30n3.pdf>. Acesso em: 10 jun. 2015.

COLACIOS, Roger Domenech. O mito do progresso: estudo de história ambiental em livros didáticos de história (1995-2002). In: ALMEIDA, Jozimar Paes de; COLACIOS, Roger Domenech. (Orgs.). Ambiente e Sociedade: trajetos de História, Ecologia Política e Educação Ambiental. Gravataí, RS: Escritos, 2011. p. 42-62. E-book.

COTRIM, Gilberto. História do Brasil: para uma Geração Consciente. São Paulo: Saraiva, 1983.

COTRIM, Gilberto. História Global: Brasil e geral. 10. ed. São Paulo: Saraiva, 2012.

CRUPI, Maria Cristina. A natureza nos livros didáticos de história: uma investigação a partir do PNLD. 2008. 119 f. Dissertação (Mestrado em Educação) - Instituto de Biociências, Universidade Estadual Paulista, Rio Claro, 2008.

ELIAS, Norbert. Os Alemães: A luta pelo poder e a evolução do habitus nos séculos XIX e XX. Rio de Janeiro: Zahar, 1997.

ESCOBAR, Arturo. La invención del Tercer Mundo: construcción y deconstrucción del desarrollo. Caracas, Venezuela: Fundación Editorial el Perro y la Rana, 2007.

ESTATÍSTICAS PNLD. Disponível em: <http://www.fnde.gov.br/programas/livro-didatico/ livro-didatico-dados-estatisticos>. Acesso em: 10 jun. 2015.

FREITAS, M. C. (Org.). Historiografia brasileira em perspectiva. 4. ed. São Paulo: Contexto, 2001.

FURTADO, Celso. O mito do desenvolvimento econômico. 3. ed. São Paulo: Paz e Terra, 1974. 
GATTI JÚNIOR, Décio. A escrita escolar da História: livro didático e ensino no Brasil (19701990). Bauru, SP: Edusc; Uberlândia, MG: Edufu, 2007.

GERHARDT, Marcos; NODARI, Eunice Sueli. Aproximações entre História Ambiental, Ensino de História e Educação Ambiental. In: BARROSO, Véra Lucia Maciel et al. (Orgs.). Ensino de História: desafios contemporâneos. Porto Alegre: EST, 2010. p. 57-72.

GILJUM, Stefan; EISENMENGER, Nina. North-South Trade and the Distribution of Environmental Goods and Burdens: a Biophysical Perspective. The Journal of Environment \& Development, v. 13, p. 73-100, mar. 2004. Disponivel em: <http://jed. sagepub.com/content/13/1/73.full.pdf+html>. Acesso em: 10 jun. 2015.

GUARESCHI, Pedrinho A. Representações sociais e ideologia. Revista de Ciências Humanas, Florianópolis, Edição Especial Temática, p. 33-46, 2000. Disponível em: <https://periodicos.ufsc.br/index.php/revistacfh/article/viewFile/24122/21517>. Acesso em: 10 jun. 2015.

HARTOG, François. Regimes de Historicidade: Presentismo e Experiências do Tempo. Belo Horizonte: Autêntica, 2014.

HOBSBWAM, Eric. A Era das Revoluções 1789-1848. 12. ed. Rio de Janeiro: Paz e Terra, 2000.

IORIS, Rafael. Transforming Brazil: a history of national development in the postwar era. New York: Taylor \& Francis, 2014.

LE GOFF, Jacques. História e Memória. 4. ed. Campinas: Ed. da UNICAMP, 1996.

LEFF, Enrique. Racionalidade ambiental: a reapropriação social da natureza. Rio de Janeiro: Civilização Brasileira, 2006.

LINHARES, Maria Yedda; SILVA, Francisco Carlos Teixeira da. Terra Prometida: uma história da questão agrária no Brasil. Rio de Janeiro: Campus, 1999.

LOEWEN, James W. Lies my teacher told me: Everything your American History Textbook got wrong. 2. ed. New York: Simon \& Schuster, 2007.

LUCCI, Elian Alabi. TDHB Trabalho Dirigido de História do Brasil: 2 Grau. São Paulo: Saraiva, 1979.

McCORMICK, John. Rumo ao Paraíso: a história do movimento ambientalista. Rio de Janeiro: Relume-Dumará, 1992. 
MEADOWS, Dennis L. et al. The Limits to Growth. New York: Universe Books, 1972.

MINORELLI, Caroline Torres. A Revolução Industrial sob a ótica da História Ambiental nos livros didáticos de História. In: ALMEIDA, Jozimar Paes de; COLACIOS, Roger Domenech (Orgs.). Ambiente e Sociedade: trajetos de História, Ecologia Política e Educação Ambiental. Gravataí, RS: Escritos, 2011. p. 80-101. E-book.

MORIN, Edgar. Ciência com Consciência. 3. ed. Rio de Janeiro: Bertrand Brasil, 1999.

MORIN, Edgar. Os Sete Saberes necessários à Educação do Futuro. 2. ed. São Paulo: Cortez, 2000.

MOTA, Myriam Becho; BRAICK, Patrícia Ramos. História: das cavernas ao terceiro milênio: da proclamação da República ao Brasil dos dias atuais: livro do professor. São Paulo: Moderna, 2005.

MUNAKATA, Kazumi. Produzindo livros didáticos e paradidáticos. São Paulo: PUC, 1994.

NADAI, Elza; NEVES, Joana. História do Brasil. 18. ed. São Paulo: Saraiva, 1996.

NADAI, Elza; NEVES, Joana. História do Brasil: da Colônia à República. 3. ed. São Paulo: Saraiva, 1982.

NOSELLA, Maria de Lourdes Chagas Deiró. As belas mentiras: a ideologia subjacente aos textos didáticos. São Paulo: Moraes, 1980.

PÁDUA, José Augusto. Natureza e projeto nacional: as origens da ecologia política no Brasil. In: PÁDUA, José Augusto et al. (Orgs.). Ecologia \& Política no Brasil. Rio de Janeiro: IUPERJ, 1987. p. 14-61.

PÁDUA, José Augusto. Produção, consumo e sustentabilidade: o Brasil e o contexto planetário. In: PARREIRA, Clélia; ALIMONA, Hector. (Orgs.). Políticas Públicas Ambientais Latino-americanas. Brasília: Faculdade Latino-Americana de Ciências Sociais, 2005. p. 169-200.

PRADO JÚNIOR, Caio. Formação do Brasil Contemporâneo. 23. ed. São Paulo: Brasiliense, 1994.

RÜSEN, Jörn. Jörn Rüsen e o ensino de história. Curitiba: Ed. UFPR, 2011.

SILVA, Francisco Carlos Teixeira da. Vargas e a Questão Agrária: A construção do fordismo possivel. Diálogos, Maringá, v. 2, n. 2, p. 113-127, 1998. 
SOARES, Andréa de Almeida Rosa; NOVICKI, Victor. Educação ambiental através de livros didáticos de história do segundo segmento do ensino fundamental. In: ENCONTRO ANUAL DA ASSOCIAÇÃO NACIONAL DE PÓS-GRADUAÇÃO E PESQUISA EM EDUCAÇÃO, 29., 2006, Caxambu. Anais... Caxambu: ANPED, 2006. p. 1-7.

SOFFIATI, Arthur. A Ausência da Natureza nos Livros Didáticos de História. Revista Brasileira de História, São Paulo, v. 9, n. 19, p. 43-56, set. 1989/fev. 1990. Disponível em: <http://www.anpuh.org/arquivo/download?ID_ARQUIVO=3878>. Acesso em: 10 jun. 2015.

SOUTO MAIOR, Armando. História do Brasil: Para o ensino de segundo grau e vestibulares. 10. ed. São Paulo: Companhia Editora Nacional, 1974.

VAINFAS, Ronaldo et al. História: volume único. São Paulo: Saraiva, 2010.

WARD, Kyle. History in the marking: An absorbing look at how American History has changed in the telling over the last 200 years. New York: The New Press, 2006.

\section{Notas}

1 Não há, portanto, uma representatividade estatística do material abordado em relação ao universo total de livros didáticos publicados. É o fundo documental consultado que permite afirmar uma representatividade do material. Ademais, cabe esclarecer, sobre a metodologia, que a leitura do material permitiu a identificação das tendências e de algumas obras exemplares. É esse grupo selecionado de obras que, em geral, são citadas no texto e que foram objeto de uma análise verticalizada.

2 Para um trabalho clássico sobre a ideologia presente no material didático, do período do regime ditatorial, no caso abordando os livros de leitura do atual primeiro ciclo do Ensino Fundamental, ver Nosella (1980).

3 Sobre o papel inovador de tal livro, ver Gatti Júnior (2007, p. 127).

4 Argumento recorrente na história Ocidental em relação com o mundo natural, ver Carvalho (2010).

5 Sendo esses os dois livros mais vendidos no PNLD 2012 (cf. ESTATÍSTICAS PNLD, s/d).

6 Contudo deve ser considerado que os livros didáticos americanos estudados nas pesquisas citadas têm uma década de diferença em relação aos congêneres brasileiros de 2012, apesar de que, para Ward (2006, p. XX), em tal periodo não haveria, em geral, mudanças significativas nos livros didáticos estadunidenses.

Ely Bergo de CARVALHO. Professor associado da Universidade Federal de Minas Gerais UFMG. Faculdade de Filosofia e Ciências Humanas, Departamento de História. Av. Antônio Carlos, 6627, Pampulha - Belo Horizonte, MG - Brasil 31270901 